\title{
Why OECD Countries Should Reform Rules of Origin
}

Olivier Cadot $\bullet$ Jaime de Melo

With preferential trade agreements on the rise worldwide rules of origin-which are necessary to prevent trade deflection-are attracting increasing attention. At the same time, preference erosion for Generalized System of Preferences (GSP) recipients is increasing resistance to further multilateral negotiations. Drawing on different approaches, this article shows that the current system of rules of origin that is used by the European Union and the United States in preferential trade agreements (including the GSP) and that is similar to systems used by other Organisation for Economic Co-operation and Development countries should be drastically simplified if developed economies really want to help developing economies integrate into the world trading system. In addition to diverting resources for administrative tasks, current rules of origin carry significant compliance costs. More fundamentally, it is becoming increasingly clear that they are often been designed to force developing economies to buy inefficient intermediate products from developed economies to "pay for" preferential access for the final product. The evidence also suggests that a significant share of the rents associated with market access (net of rules of origin compliance costs) is captured by developed economies. Finally, the restrictiveness of rules of origin is found to be beyond the levels that would be justified to prevent trade deflection, suggesting a capture by special interest groups. The article outlines some alternative paths to reforms. JEL codes: F13, F15

Rules of origin are an integral part of proliferating free trade agreementscountries belong to an average of six, according to a recent tally by the World Bank (2005, table 2.1) —and nonreciprocal preferential trade agreements such as the Generalized System of Preferences (GSP). ${ }^{1}$ Given the lack of progress on harmonization at the World Trade Organization (WTO) and given that regionalism is here to stay, rules of origin are likely to be increasingly important in the world trading system.

(C) The Author 2007. Published by Oxford University Press on behalf of the International Bank for Reconstruction and Development / THE WORLD BANK. All rights reserved. For permissions, please e-mail: journals.permissions@oxfordjournals.org doi;10.1093/wbro/lkm010 Advance Access publication October 4, 2007 
The primary justification for rules of origin in preferential trade agreements is to prevent "trade deflection," or taking advantage of low external tariffs or weak customs-monitoring capacities to bring in imports destined for more protected markets in a trading bloc (possibly after superficial conditioning or assembly). In effect, rules of origin are needed to prevent trade deflection for all preferential trade agreements short of customs unions, where trade deflection is not an issue because members have a common external tariff. Beyond the largely unimportant issue of tariff revenue, what is at stake is the unwanted extension of preferences to out-of-bloc producers, which would erode the value of those preferences to eligible producers. In preferential trade agreements between developed and developing economies, rules of origin are also sometimes justified on "developmental" grounds because they can help foster integrated manufacturing activities in developing economy partners.

However, this article provides evidence that, by their complexity, rules of origin impose substantial compliance costs on preferred producers. For instance, in addition to regime-wide rules, the European Union has more than 500 productspecific rules of origin (Cadot, de Melo, and Pondard 2006). As a result, these rules are increasingly difficult to observe. In the least developed economies the rules divert scarce customs resources from other tasks such as trade facilitation. ${ }^{2}$ In preferential trade agreements between developed and developing economies, forcing developing economy producers to source relatively inefficient intermediate goods locally or from developed economy partners rather than from the most price-competitive sources (as in, say, Asia) increases inefficiency and raises costs. The result is reduced value of preferences (compounding preference erosion in particular for least developed economies) and rent creation for developed country producers.

This potential for rules of origin to become a form of "export protection" was first observed by Krueger (1998) during negotiations for the North American Free Trade Agreement (NAFTA). It applies to all preferential trade agreements (including nonreciprocal preferential schemes) granted by Organisation for Economic Co-operation and Development (OECD) countries to developing economies. Moreover, there is an overwhelming evidence that this protectionist effect of rules of origin is not incidental but by design. Because rules of origin, unlike more traditional forms of trade protection such as voluntary export restraints or antidumping provisions, have so far largely escaped WTO disciplines; they are thus potentially a choice instrument for creeping protectionism.

New evidence reported in this article shows that the burden imposed by the rules of origin applied by the two main protagonists in preferential trade agreements, the European Union and the United States, is substantial whenever preferential margins are anything more than negligible. All told, the detailed evidence gathered here suggests that the current system of rules of origin applied by 
developed economies is out of hand and defeats both the spirit of reforms aimed at bringing greater transparency to the multilateral trading system and the development-friendly intent of preference schemes.

In a recent communication, the European Union decided to consider simplifying its rules of origin. ${ }^{3}$ However, other OECD countries have so far refrained from reforming their rules and have opposed any discussion of reform of preferential rules of origin at the WTO. This article is a contribution to an overdue debate on how to design benign, transparent, and WTO-compatible rules of origin.

This article is organized as follows. The first section briefly recounts how product-specific rules of origin are defined in EU and U.S. preferential schemes and proposes an ordinal restrictiveness index summarizing their complexity. This index is shown to be correlated with EU and U.S. most favored nation tariffs (and thus, with the depth of trade preferences). The second section presents a simple framework for quantifying the costs associated with rules of origin: distortionary, administrative, and rent-transfer. The third section provides direct evidence of the effect of rules of origin on preference use and rent sharing using preference utilization rates and unit values. The fourth section qualifies the direct evidence by considering the Asian exception and the natural experiment provided by comparing the EU Everything But Arms initiative and the U.S. African Growth and Opportunity Act (AGOA), which have similar tariff-preference margins but different rules of origin. The fifth section provides further indirect evidence. The sixth section draws policy implications from the article's findings and makes recommendations for simplifying existing rules of origin.

\section{Rules of Origin: Definition and Measurement}

Rules of origin in preferential trade agreements have two components: a small set of regime-wide rules and a large set of product-specific rules, typically defined at the Harmonized System six-digit level of disaggregation (HS-6). Both rules together are to ensure sufficient transformation. Because the European Union and the United States are the main users of preferential trade schemes among OECD countries, this article follows the approach of Cadot, de Melo, and Portugal-Perez (2005), describing briefly the rules for NAFTA, which have been in place for a long time and correspond closely to those applied by the United States in other preferential trade agreements, and those for the European Union's "Pan-European system (PANEURO), "also called the "single-list" because it covers the common set of product-specific rules of origin that the European Union applies in all its preferential trade agreements (regime-wide rules differ across the European Union's preference schemes such as the GSP or Cotonou Agreement). The analysis starts with regime-wide rules then turns to product-specific rules of origin. 


\section{Regime-wide Rules}

Regime-wide rules usually include five components (these and other terms are defined in the glossary at the end of the article):

- A de minimis (or tolerance) criterion that stipulates the maximum percentage of nonoriginating materials that can be used without affecting the origin of the final product.

- A cumulation rule.

- A provision on whether "roll-up" applies.

- The status of duty drawbacks.

- The applicable certification method.

Table 1 describes how these regime-wide rules differ between the European Union and the United States.

Table 1. EU and U.S. Examples of Regime-wide Rules of Origin

\begin{tabular}{|c|c|c|c|c|c|}
\hline $\begin{array}{l}\text { Preferential trade } \\
\text { agreement }\end{array}$ & $\begin{array}{c}\text { De minimis or tolerance } \\
\text { rule }\end{array}$ & $\begin{array}{l}\text { Absorption } \\
\text { (roll up) }\end{array}$ & Cumulation & $\begin{array}{l}\text { Drawback } \\
\text { allowed }\end{array}$ & Certification method \\
\hline NAFTA & $\begin{array}{l}7 \text { percent (except } \\
\text { agricultural and } \\
\text { industrial products), } \\
7 \text { percent of weight } \\
\text { for goods in chapters } \\
50-63\end{array}$ & $\begin{array}{l}\text { Yes (except } \\
\text { autos) }\end{array}$ & Bilateral & $\begin{array}{l}\text { Not after } 7 \\
\text { yrs }\end{array}$ & Self-certification \\
\hline $\begin{array}{l}\text { United States- } \\
\text { Chile }\end{array}$ & $\begin{array}{l}10 \text { percent (except } \\
\text { agricultural and } \\
\text { processed agricultural } \\
\text { products) }\end{array}$ & Yes & Bilateral & $\begin{array}{l}\text { Not } \\
\text { mentioned }\end{array}$ & Self-certification \\
\hline U. S.-GSP & $\begin{array}{l}10 \text { percent, } 10 \text { percent } \\
\text { of weight for goods in } \\
\text { chapters } 50-63\end{array}$ & $\begin{array}{l}\text { Not } \\
\text { mentioned }\end{array}$ & $\begin{array}{l}\text { Bilateral, } \\
\text { limited } \\
\text { diagonal }\end{array}$ & $\begin{array}{l}\text { Not } \\
\text { mentioned }\end{array}$ & Self-certification \\
\hline $\begin{array}{l}\text { Cotonou } \\
\text { Agreement }\end{array}$ & 15 percent & Yes & Full & $\begin{array}{l}\text { Not } \\
\text { mentioned }\end{array}$ & $\begin{array}{l}\text { Two-step private } \\
\text { and public and } \\
\text { limited self- } \\
\text { certification }\end{array}$ \\
\hline EU GSP & $\begin{array}{l}10 \text { percent (except } \\
\text { goods in chapters } \\
50-63)^{\mathrm{a}}\end{array}$ & Yes & $\begin{array}{l}\text { Bilateral, } \\
\text { limited } \\
\text { diagonal }\end{array}$ & $\begin{array}{l}\text { Not } \\
\text { mentioned }\end{array}$ & $\begin{array}{l}\text { Two-step private } \\
\text { and public and } \\
\text { limited self- } \\
\text { certification }\end{array}$ \\
\hline
\end{tabular}

Note: Classification is carried out at the six-digit Harmonized System tariff line level. Each cell is the percentage of tariff lines that have the rules of origin in the corresponding row and in the corresponding column.

${ }^{\text {a }}$ Goods in chapters 50-63 (textiles and apparel) do not benefit from a de minimis provision.

Source: Cadot, de Melo, and Portugal-Perez 2005, table 1. 
Even for regime-wide rules, table 1 gives the impression of "made-to-measure" rules. It also shows that regime-wide rules differ across preferential trade agreements for the same developed economy partner, confirming the hub-and-spoke characteristic of preferential trade agreements between developed and developing economies. Certification methods also differ between EU and U.S. preferential trade agreements; certification is easier to carry out in U.S. agreements, at least in principle, than in EU ones.

\section{Product-Specific Rules of Origin}

Devising methods for determining sufficient processing (or substantial transformation) has turned out to be very complex in all existing preferential trade agreements because the Harmonized System was not designed to define the origin of goods. Three criteria are used by the European Union and the United States to determine whether sufficient transformation has taken place in activities requiring processing (that is, anything but crude products):

- A change of tariff classification (at various levels of the Harmonized System), meaning that the final product and its imported components should not belong to the same tariff classification (in other words, that the local processing should be substantial enough to induce a change of tariff classification).

- A critical threshold for value added (in short, a value content rule).

- A specific manufacturing process (a so-called "technical requirement").

For crude products the typical rule is "wholly obtained," which permits no foreign content whatsoever, although other rules apply in special cases, such as fish products.

Both NAFTA (whose rules are also used in other U.S. preferential trade agreements) and PANEURO have a long list of criteria-including such technical requirements as the "triple transformation" requirement in textiles and apparel, which requires apparel to be woven from originating fabric and yarn. Criteria also include exceptions (making them more stringent) and allowances (making them less stringent). NAFTA relies more heavily on changes of tariff classification, though often in combination with other criteria. PANEURO relies mostly on value content and wholly obtained criteria, with wholly obtained criteria prevalent for GSP and African, Caribbean, and Pacific (ACP) exports of primary products with little processing.

As Krishna (2006) points out, when analyzing rules of origin, the devil is in the details because the complexity of rules of origin is what provides an opportunity for special interests to influence their design and administration. While many facets of rules of origin have been explored, rigorous empirical study of their 
effects has been hampered by two difficulties, one relating to data on utilization rates, the other to measurement of the rules' restrictiveness.

First, data on preference utilization have been made freely available to the public only recently for the United States but not yet for the European Union ( for example, Brenton and Manchin 2003 and the studies collected in Cadot, Estevadeordal et al. 2006).

Second, because rules of origin are a set of complex, heterogeneous legal rules, it has proved difficult to develop a reliable measure of their restrictiveness to serve as a synthetic indicator (much like effective rates of protection are a synthetic indicator of the restrictiveness of a country's trade regime). Estevadeordal (2000) has proposed an ordinal index of product-specific rules of origin restrictiveness (or $R$-index), taking values between one and seven, with higher values corresponding to more restrictive rules of origin. The index, constructed from a simple observation rule at the HS-6 level, where rules of origin are defined, is described below.

The observation rule is as follows (Cadot, de Melo, and Portugal-Perez 2005). Let $\mathrm{CC}$ stand for a change of chapter, $\mathrm{CH}$ for a change of heading, $\mathrm{CS}$ for a change of subheading, and $C I$ for a change of item. A change of classification at the item level can be taken as less stringent than one at the subheading level, and so forth. So the criterion for classifying changes of tariff classification criteria is

$$
\mathrm{CC}>\mathrm{CH}>\mathrm{CS}>\mathrm{CI}
$$

But a change of tariff classification is often accompanied by one or two (in a few cases even three) additional requirements, such as value content rules, technical requirements, exceptions, or allowances. The observation rule assigns higher index values to changes of tariff classification when these requirements are added and lower ones in the case of allowances. For instance, a change of heading is given an index value of four, which rises to a five when accompanied by a technical requirement or exception but shrinks to three when accompanied by an allowance.

Though not amenable to quantification as effective rates of protection, the $R$-index plays the same analytical role; it is intended as an overall indicator of how trade-inhibiting the requirements that must be met by a product to obtain originating status. There is preliminary evidence that preferences have hidden compliance costs and that those compliance costs may be related to rules of origin. Table 2 shows evidence for the textile and apparel sector under NAFTA, the EU GSP, and the Cotonou Agreement (which grants tariff-free access for most ACP products to the EU market). ${ }^{4}$ Although NAFTA's and Cotonou's preference margins are equal, at 10.4 percentage points, their utilization rates vary widely: 50 percent for Cotonou compared with 79.9 for NAFTA. Cotonou's low rate of uptake despite deep preferences suggests hidden barriers. ACP countries benefit from full rather than diagonal cumulation (that is, intermediate purchases from 
Table 2. Preferences and Utilization Rates for Textiles and Apparel

\begin{tabular}{lccc}
\hline Preferential trade agreement & $\begin{array}{c}\text { Number of } \\
\text { observations }\end{array}$ & $\begin{array}{c}\text { Utilization rate } \\
\text { (percent) }\end{array}$ & $\begin{array}{c}\text { Preference margin } \\
\text { (percentage points) }\end{array}$ \\
\hline NAFTA (2001) & 618 & 79.9 & 10.4 \\
EU GSP (2004) & 16,555 (HS-8) & 52.2 & 1.8 \\
Cotonou Agreement (2004) & 12,920 (HS-6) & & 10.4 \\
\hline
\end{tabular}

Note: Averages are unweighted. HS-6 is the six-digit Harmonized System level; HS-8 is the eight-digit Harmonized System level.

Source: Cadot, de Melo, and Portugal-Perez (forthcoming), table 3b.

Table 3. Preferences and Utilization Rates, All Goods

\begin{tabular}{lrcc}
\hline & \multicolumn{3}{c}{ Preference margin } \\
\cline { 2 - 4 } Preferential trade agreement & $\tau \geq 4$ percent $^{a}$ & $\tau \geq 8$ percent $^{a}$ & $\tau \geq 12$ percent $^{a}$ \\
\hline North American Free Trade Agreement $^{\mathrm{b}}$ & $87(1,239)$ & $86.0(558)$ & $82.8(287)$ \\
GSP $^{\mathrm{c}}$ & $50.2(1,297)$ & $52.5(91)$ & $66.2(44)$ \\
Cotonou Agreement $^{\mathrm{c}}$ & $92.5(1,627)$ & $94.3(892)$ & $96.4(566)$ \\
\hline
\end{tabular}

Note: Averages are unweighted. Numbers in parentheses are the number of tariff lines.

${ }^{\mathrm{a}} \tau_{i}=\left(t_{i}^{M F N}-t_{i}^{\text {PREF }}\right) /\left(1+t_{i}^{\text {PREF }}\right)$ is the preference margin.

${ }^{\mathrm{b}}$ Computed at the six-digit Harmonized System tariff-line level with 2001 data.

${ }^{\mathrm{c}}$ Computed at the eight-digit Harmonized System tariff-line level with 2004 data for 92 countries (GSP) and 37 countries (Cotonou Agreement) qualifying for preferential market access.

Source: Cadot, de Melo, and Portugal-Perez. (forthcoming), table 2.

all partners qualify as originating) and a 15 percent tolerance rule compared with only 10 for the GSP, which also excludes the textile and apparel sector (chapters 50-63) from the 10 percent tolerance rule.

Table 3 shows that the evidence of hidden costs goes beyond the textile and apparel sector, where differences in uptake at similar margins may reflect composition effects. Define the preferential margin $\tau$ by the normalized difference between most favored nation and preferential tariffs

$$
\tau_{i}=\frac{t_{i}^{\mathrm{MFN}}-t_{i}^{\mathrm{PREF}}}{1+t_{i}^{\mathrm{MFN}}}
$$

Table 3 shows that, contrary to expectations, when the preferential margin rises, utilization rates fall for NAFTA. This suggests that an omitted variable is positively 
Table 4. Tariff Peaks and the R-index

\begin{tabular}{lcc}
\hline & \multicolumn{2}{c}{ Restrictiveness-index value } \\
\cline { 2 - 3 } & North American Free Trade Agreement & PANEURO \\
\hline Tariff peaks $^{\mathrm{a}}$ & $6.2(257)$ & $5.2(780)$ \\
Low tariffs & $4.8(1,432)$ & $3.9(3,241)$ \\
Total number of tariff lines & 3,555 & 4,961 \\
\hline \multicolumn{2}{l}{ Note: Numbers in parentheses are numbers of tariff lines. Restrictiveness indexes are unweighted. } \\
a Tariff lines whose tariffs exceed three times the GSP average. \\
b Tariffs lines whose tariffs are less than one-third of the GSP average. \\
Source: Cadot, de Melo, and Portugal-Perez 2005, table 3. \\
\hline
\end{tabular}

correlated with tariffs but negatively correlated with preference utilization. Rules of origin are an obvious culprit.

Table 4 shows that lines with tariff peaks (that is, with tariffs more than three times the average), where preferential margins are highest, do have higher $R$ index values than those with low tariffs. This relationship holds for both NAFTA and PANEURO.

Figure 1 confirms the patterns in tables 2-4; utilization rates do not really increase with tariff-preference margins. For NAFTA, they actually decrease due largely to the influence of the textile and apparel sector, where tariff preferences are deep and rules of origin stringent.

\section{Quantifying the Effects of Rules of Origin}

Although product-specific rules of origin, as already noted, take a variety of legal forms (changes of tariff classification, value content rules, technical requirement, and the like), they can all be represented conceptually as floors on domestic value added. Suppose that a producer in Madagascar wishes to sell a shirt under preferential access in the European Union, this shirt is made with both originating intermediate goods (that is, intermediate goods that are either local, EU-made, or imported from other qualifying countries, according to cumulation rules) and nonoriginating intermediate goods, say from Bangladesh, China, or India. Now assume that to satisfy origin requirements (whether change of tariff classification, value content rule, or technical requirement), the Malagasy producer uses a higher proportion of originating inputs than would be the case in the absence of rules of origin (which is precisely the rule's purpose).

Let superscript $R$ denote a choice restricted by rules of origin. Unrestricted value added is $v a_{i}$, and restricted value added is $v a_{i}^{\mathrm{R}}$, so rules of origin content 
Figure 1. Average Utilization Rates for Different Preferential Margin Thresholds

\begin{tabular}{|r|r|}
\hline & \\
GSP & NAFTA \\
\hline 43.7 & 86.1 \\
\hline 50.2 & 87 \\
\hline 56.8 & 86.4 \\
\hline 52.5 & 86 \\
\hline 71.4 & 84.8 \\
\hline 66.2 & 82.8 \\
\hline 46.8 & 81.9 \\
\hline 45.4 & 77.8 \\
\hline 55.9 & 78.5 \\
\hline 54.7 & 76.6 \\
\hline
\end{tabular}

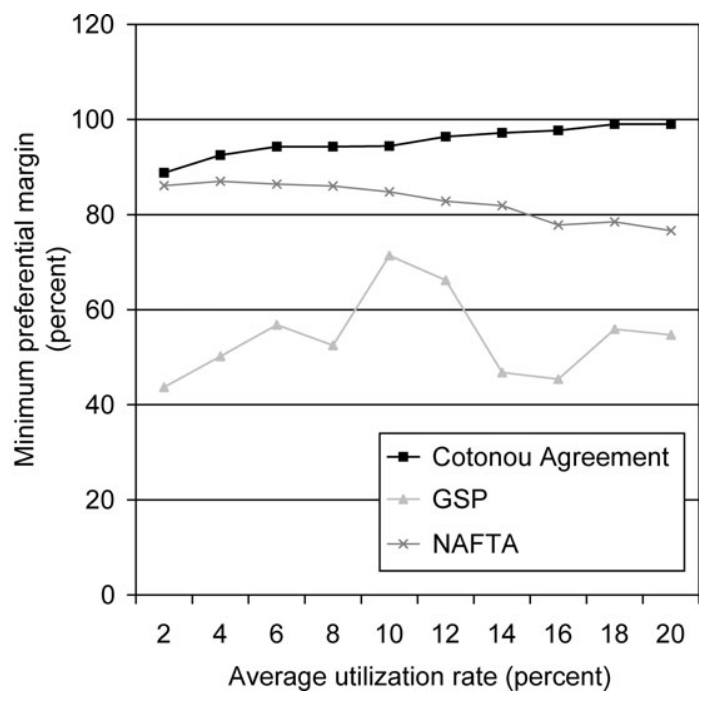

Note: Cotonou Agreement includes 37 countries, computed at the eight-digit Harmonized System level; GSP includes 92 countries, computed at the eight-digit Harmonized System level; and the NAFTA includes 3 countries, computed at the six-digit Harmonized System level. Data are unweighted averages computed at the most disaggregated tariff-line level (table 2). Averages are based on more than 100 observations except for GSP (minimum of 27 observations for preference margins, $\tau$, equal to or greater than 20 percent.).

Source: Cadot, de Melo, and Pondard 2006.

reduces to $v a_{i}^{\mathrm{R}}>v a_{i}$, whether or not it explicitly takes the form of a value content rule. Thus, conceptually a value content rule can be thought of as a generic rule that can play the role of all others by quantifying the objective common to all. This principle is important because it underlies an approach to rules of origin reform, discussed later, that substitutes a value content rule-possibly, although not necessarily, at differentiated rates across products-for the current array of instruments. It also highlights how information on rules of origin restrictiveness can be aggregated across instruments and subsumed into a single restrictiveness index, which itself can be then aggregated across product lines by averaging.

Five results emerge from the quantitative analysis of the relationship between rules of origin restrictiveness and preference uptake:

For a given preference margin a higher restrictiveness index translates into a lower utilization rate, all other things being equal.

For a given restrictiveness index a higher tariff-preference margin translates into a

higher utilization rate, all other things being equal. 
The compliance decisions of individual firms are binary; how the decisions aggregate into industry-wide utilization rates depends on the unobserved distribution of compliance costs.

A lower pass-through of tariff preferences for the least developed economies (due to low bargaining power) implies lower uptake of preferences, all other things being equal.

Improvements in the uptake of preferences can be obtained either from reductions in the restrictiveness of rules of origin or from cost-reducing administrative simplifications (such as transparent and uniform criterion).

The third result implies that the statistical relationship between $R$-index values, preference margins, and utilization rates can only be "noisy" (that is, affected by a large unexplained component) at the aggregate (product-line) level. But notwithstanding the noise introduced by unobserved firm characteristics (which could be investigated only with firm-level data that are not currently available), figure 1 suggests an unambiguous relationship between preference margins, rules of origin restrictiveness, compliance costs, and utilization rates. It also suggests that, without a proxy for rules of origin restrictiveness such as the $R$-index, attempting to evaluate the effect of tariff-preference margins on the uptake of those preferences may lead to omitted-variable bias.

Keeping in mind that this framework captures only some of the effects associated with rules of origin, several observations are in order. ${ }^{5}$ First, administrative costs act as a technical barrier to trade; they result in resource waste, and in the welfare calculus of the effects of rules of origin they are more costly than the usual deadweight losses. Second, if costs are associated with certification, requests for preferential status would not be observed when preference margins are low. Third, compliance costs are particularly high for differentiated products, for which there can be quality as well as price differences between eligible (local) and noneligible intermediate goods. Because part of those costs is passed on to consumers in the countries that determine the rules of origin, high utilization rates does not necessarily imply that rules of origin have small effects.

Stiff rules of origin may inhibit or deflect trade altogether, not just the uptake of preferences. This was shown in the case of the Europe Agreements, free-trade agreements signed in 1991 between the European Union and the Central and Eastern European countries. Tumurchudur (2007a) showed that a large share of the exports from Central and Eastern Europe was deflected from EU markets by rules of origin, resulting in heavy losses. Evidence of trade-inhibiting effects is also apparent in the evolution of textile and apparel exports under AGOA and the Everything But Arms initiative, which is discussed in the exception and quasinatural experiment section below. 


\section{Direct Evidence}

In the absence of firm-level data Carrère and de Melo (2006) assume that the preference utilization rate for product line $i$ (the percent of exports sent under the preferential regime rather than the most favored nation one), referred to as $U i$, rises with the tariff-preference margin, $\tau_{i}$ (which may be just equal to the most favored nation tariff when preferential access means tariff-free access) and shrinks with rules of origin compliance costs $c_{i}^{R}$. That is, $U_{i}=f\left(\tau_{i}-c_{i}^{R}\right)$ where $f(\cdot)$ is an increasing function, and, $c_{i}^{R}=\left(R o O_{i}\right)$, where $g(\cdot)$ is an increasing function (true compliance costs are firm-specific and are thus unobserved; all that is observed is the presence of $\mathrm{RoO}_{i}$ ). These assumptions lead to an estimable relation of the form

$$
u_{i}=\lambda+\alpha \tilde{\tau}_{i}+\sum_{k} \theta_{k} R o O_{i k}+\varepsilon_{i}
$$

where $\mathrm{RoO}_{i k}$ is a set of dummy variables indicating the presence of product-specific rules of origin (change of tariff classifications, exceptions, and so on). Results from estimating equation (3) on NAFTA data confirm that utilization rates rise with preferential margins and shrink in the presence of rules of origin (Cadot, de Melo, and Portugal-Perez 2005 for results using data for the European Union).

Carrère and de Melo (2006) combined their estimates with $R$-index values to compute an estimated ad valorem equivalent of total rules of origin compliance costs (administrative costs and costs due to higher input costs). Their estimates range from 3.5 percent for a change of chapter to more than 15 percent for combinations of rules of origin involving technical requirements. The strongly inhibiting effect of technical requirements appears to be an empirical regularity.

Even if the estimates are robust to a range of specifications, it is difficult to infer a sense of robustness from estimates derived from a relation like equation (3) because so much heterogeneity and so many "unobservables" influence preference uptake. Estimates have proved fairly sensitive to the inclusion of control variables, in particular when using EU GSP data.

An alternative is to restrict the analysis to products, for which the sole criterion used to determined origin is a value content. Drawing on the variation in EU value content criteria across product lines with value content the sole criterion, Cadot, Carrère, and Strauss-Kahn (2007) estimate an equation similar to equation (3), in which however the dummy variables for rules of origin are replaced with the continuous value content rule values. ${ }^{6}$ Using dummy variables for Harmonized System sections to control for heterogeneity across sectors and restricting the sample to tariff lines with substantial tariff-preference margins (above 2 or 5 percent), they find that utilization rates rise, all other things being equal, with the maximum foreign content allowed by the value content rule. 
Table 5. Estimated Effects on Preference Utilization and Rent Transfer of Relaxing a Value Content Requirement

\begin{tabular}{|c|c|c|c|c|}
\hline & \multicolumn{4}{|c|}{ Preference margin } \\
\hline & $\begin{array}{c}\tau_{i} \geq 2 \% \\
A C P+G S P\end{array}$ & $\begin{array}{c}\tau_{i} \geq 5 \% \\
A C P+G S P\end{array}$ & $\begin{array}{c}\tau_{i} \geq 2 \% \\
\text { GSP }\end{array}$ & $\begin{array}{c}\tau_{i} \geq 5 \% \\
\text { GSP }\end{array}$ \\
\hline Number of observations & 19,261 & 5,958 & 13,448 & 4,305 \\
\hline Mean preferential margin $(\bar{\tau})$ (percent) & 3.74 & 5.14 & 3.79 & 5.22 \\
\hline Mean utilization rate (percent) & 0.12 & 0.17 & 0.17 & 0.22 \\
\hline Mean value content (percent of unit price) & 58.8 & 58.2 & 58.9 & 58.6 \\
\hline Mean value of imports (euros) & $1,475,182$ & $2,376,301$ & 986,979 & 159,694 \\
\hline \multicolumn{5}{|c|}{ Simulation: local content requirement reduced by 10 percentage points } \\
\hline $\begin{array}{l}\text { Change in preference utilization rate } \\
\text { (percentage points) }\end{array}$ & 2.0 & 5.2 & 2.5 & 1.7 \\
\hline $\begin{array}{l}\text { Total rent transfer from increased } \\
\text { utilization (millions of euros) }\end{array}$ & 21. 7 & 37.4 & 25.3 & 11.6 \\
\hline
\end{tabular}

${ }^{\mathrm{a}}$ Evaluated at the mean value of imports.

Source: Authors' computations based on Cadot, de Melo, and Portugal-Perez (forthcoming), table 6.

Since a single value content criterion is a serious candidate for reform, at least in the case of the European Union (Stevens et al. 2006 and Cadot, de Melo, and Pondard 2006), table 5 reports two illustrative simulations based on these estimates. The mean local content requirement is 58 percent and preference margin 3-5 percent depending on the sample; mean utilization rates are rather low-between 12 and 22 percent. The bottom of the table shows the first-round effects (no supply response) of reducing the local-content requirement by 10 percentage points. Utilization rates rise by $2-5$ percentage points (row 6), raising the rent transfer by $€ 21-37$ million, for a mean value of imports of $€ 1.5-3.0$ billion.

To fully grasp the welfare effects of rules of origin, the rent distribution between the exporting and importing country must be factored in. This implies estimating the pass-through effect of tariffs on consumer prices (that is, the extent to which preferences translate into a higher producer price for exporters). Estimates for AGOA preferences (Olarreaga and Özden 2005) and for the Caribbean Community (Özden and Sharma 2006) are that between one-third and one-half of tariff reductions are passed on to producers.

However, part of the border-price increase could reflect the compliance costs discussed above. Using a monopolistic-competition model with differentiated products in which Mexican exporters can export product $j$ either to the rest of the world (under most favored nation status, at price $p_{j}^{M}$ ) or to the 
Table 6. Exports, Unit Costs, and Prices under Preferential Market Access and a Binding Minimum Local Content Requirement

\begin{tabular}{|c|c|c|c|c|c|}
\hline & \multicolumn{5}{|c|}{ Simulations } \\
\hline & (1) & (2) & $(3)^{a}$ & (4) & (5) \\
\hline Preference margin (percent) & 10 & 10 & 10 & 10 & 10 \\
\hline $\begin{array}{l}\text { Administrative unit costs (percent of } \\
\text { unit price) }\end{array}$ & 0 & 0 & 0 & 2.5 & 1.0 \\
\hline $\begin{array}{l}\text { Unconstrained, minimum local content } \\
\text { requirement (percent of unit price) }\end{array}$ & 40 & 40 & 40 & 40 & 36 \\
\hline $\begin{array}{l}\text { Constrained, minimum local content } \\
\text { requirement (percent of unit price) }\end{array}$ & & 50 & 50 & 50 & 40 \\
\hline $\begin{array}{l}\text { Preferential exports (percent change } \\
\text { from scenario with no preferential } \\
\text { access) }\end{array}$ & 15.9 & 11.1 & -0.15 & 7.1 & 10.7 \\
\hline $\begin{array}{l}\text { Unit costs (percent change from } \\
\text { scenario with no preferential access) }\end{array}$ & 0 & 1.9 & 6.7 & 1.9 & 0.4 \\
\hline $\begin{array}{l}\text { Unit net price (percent change from } \\
\text { scenario with no preferential access) }\end{array}$ & 2.9 & 3.0 & 3.4 & 2.2 & 2.1 \\
\hline
\end{tabular}

Note: Unit net price set equal to 1, initial output to 100, and value-added to 20. All output is exported (40 percent to preference-receiving destination). For columns 1-4 nonoriginating inputs are set to 75 percent of intermediate good input purchases. This implies that initial (unconstrained) local content is $20+0.25(80)=$ 40. Setting the minimum local content requirement at 50 percent implies reducing nonoriginating intermediate goods to 62.5 percent of intermediate good purchases. For column 5 nonoriginating inputs are set at 80 percent and reduced to 75 percent through the minimum local content rule.

${ }^{a}$ Same as column 2 but with low value for the elasticity of substitution between originating and nonoriginating materials (0.5 instead of 2$)$.

Source: Authors' computations adapted from model in Cadot et al. 2005.

United States (under NAFTA, at price $p_{j}^{N}$ ), Cadot et al. (2005) estimate the following relationship

$$
\text { NAFTA markup }=\alpha_{0}+\alpha_{1} \tau_{j}+\alpha_{1} C C_{j}+\alpha_{3} \text { TECH }_{j}+\varepsilon_{j}
$$

where "NAFTA markup" is the percentage by which Mexico's NAFTA shipment prices are raised over comparable most favored nation shipment prices, $C C_{j}$ is a dummy variable marking a change of tariff classification at the chapter level, and $\mathrm{TECH}_{j}$ is a dummy variable marking a change of a technical requirement.

When estimated at the HS-8 level, equation (4) is the best tool to compare prices in different markets. With complete pass-through $(\mu=1$ in equation (4) the estimated coefficient for $\alpha_{1}$ would be close to one, but Cadot et al. (2005) find it substantially below one. They also obtain negative and significant estimates for $\left(\alpha_{2}, \alpha_{3}\right)$ indicating that rules of origin costs are at least to some extent passed on to consumers. Once rules of origin are taken into account, the backward 
pass-through of preferences to producer prices falls from 80 percent of the margins to only 50 percent. They also show, using input-output links, that U.S. producers of intermediate goods are able to retain a substantial share of the rents generated by rules of origin downstream. That is, stiff rules of origin on, say, Mexican shirts exported to the United States significantly raise the price of fabric exported by the United States to Mexico for use in those shirts. This reflects the fact that rules of origin create a captive market for U.S. intermediate goods.

\section{An Exception and a Quasi-Natural Experiment}

The covariation of utilization rates and margins does not account for all the effects of rules of origin. Case studies such as those reported in Cadot, de Melo, and Pondard (2006) and Stevens et al. (2006) provide useful complementary evidence, although they conclude that each case is different, thereby explaining if not justifying the current maze. An exception and a quasi-natural experiment are drawn here, with both suggesting that rules of origin are, as they stand, unnecessarily restrictive.

\section{Asian Exception}

In a world where rules of origin are as cumbersome and complicated as they are (Estevadeordal and Suominen 2006 for a detailed description), Association of Southeast Asian Nations (ASEAN), Free Trade Area (AFTA) and the ASEANChina Free Trade Area (ACFTA) stand out as exceptions. To obtain originating status (that is, to fulfill the criterion of sufficient processing), either the wholly obtained criterion (for a few agricultural products) or a single-value content rule requiring 40 percent local content (for most products) is used. This rule has been relaxed by allowing a choice between criteria for countries that found it too constraining. For instance, under ACFTA the importer can choose a change of tariff classification can be used as an alternative to the 40 percent local content for obtaining origin for leather goods, and some specific process criteria are also accepted for some textile products. ${ }^{7}$

So why are rules of origin under AFTA less stringent than elsewhere? First, until recently Asian regionalism was more about cooperation than about preferential trade. Under the aegis of the United States, Asia-Pacific Economic Cooperation was set up specifically to avoid preferential trade and the formation of an Asian trade bloc. Much of the region's integration in the world economy has been driven by unilateral tariff reductions. Second, regional trade has made possible the rise of the Asian manufacturing matrix in which labor-intensive stages of production initially carried out in Japan-and later in the Republic of 
Korea-were outsourced to the region's lower wage countries. The resulting regional production networks have contributed to the price-competitiveness of Asia's exports, which has benefited the whole region. Stiff rules of origin would have jeopardized this successful model.

This "Asian exception" has been conducive to the successful development of Asian countries that have fully participated in "verticalizing" trade (the development of cross-border supply chains generating trade in intermediate products). In this unusual setup (relative to other global trading patterns), intraregional trade in politically sensitive final products where protection is highest was insignificant. Thus, the political-economy forces that would usually lead to the complex rules of origin observed elsewhere have not been at work so far. As a result, low-income countries such as Cambodia and Lao PDR have been able to participate in the fragmentation of production according to comparative advantage. ${ }^{8}$ Arguably, Asia's simple and uniform rules of origin requirement is an example of the kind of rules of origin that would really be development-friendly.

\section{AGOA and Everything but Arms: a Natural Experiment}

In the textile and apparel sector, the choice area for obscure and trade-inhibiting rules of origin, the one notable exception is the U.S. preferences granted to 22 Sub-Saharan African least developed economies under AGOA. Thus, comparing African apparel exports to the European Union and the United States provides a quasi-experimental situation in which the effects of rules of origin on the uptake of trade preferences are analyzed. This quasi-experimental situation, first studied by Brenton and Özden (2005), comes from the combination of different rules of origin with very similar rates of preference margins (textiles and apparel receive approximately the same protection in the EU and U.S. markets. In 2001 the EU15's most favored nation tariff was 10.1 percent compared with 11.7 percent for the United States, and duty-free access applied to both Everything But Arms eligible and the 34 AGOA-eligible African countries).

To qualify for preferential access to the U.S. market, an exporter must prove that the garments are produced, cut, and sewn in the area benefiting from preferential access (here, AGOA). Cotton products must be made from originating fabric, yarn, and thread, with diagonal cumulation somewhat relaxing the requirement, since fabric originating in other member countries qualifies. However, this rule, known as "the triple transformation" rule, was relaxed for 22 least developed economies under AGOA's "special regime," which permits the use of third-country fabric. ${ }^{9}$ That is, the special regime reduces the transformation requirement to a single transformation (from fabric to garment).

Fifteen of AGOA's special regime beneficiaries are also eligible for the European Union's Everything But Arms initiative. But no such relaxation applies to exports 
to the European Union under either the Cotonou Agreement or Every But Arms preferences. EU rules of origin for apparel require production from originating yarn, which implies a "double transformation" from yarn to fabric and from fabric to clothing. The European Union's “double-transformation” rule obviously makes compliance difficult for countries that have no textile industry. Small or poor countries that cannot profitably produce fabric-weaving is a capital-intensive activity involving expensive machinery, particularly for woven productsshould not, from an economic-efficiency viewpoint, set up the vertically integrated local value chains that would satisfy the double-transformation rule.

In apparel preference utilization rates are very high under both AGOA (97.36 percent in 2004) and Everything But Arms/Cotonou (94.9 percent). Cotonou has rules similar to those that Everything But Arms has for apparel. However, export volumes evolved quite differently for the 15 least developed economies that benefit from both schemes. Figure 2 shows a substantial increase in the value of apparel exports with AGOA's entry into force in 2000 (in particular for Lesotho and Madagascar). By contrast, the value of exports from this same group of countries did not rise following the adoption of Everything But Arms-in fact it fell slightly. Of course, the exports that remained flat for those countries should come as no surprise since they already benefited from Cotonou preferences, which give almost

Figure 2. Apparel Exports of 22 Countries Benefiting from the AGOA Special Regime, 2004

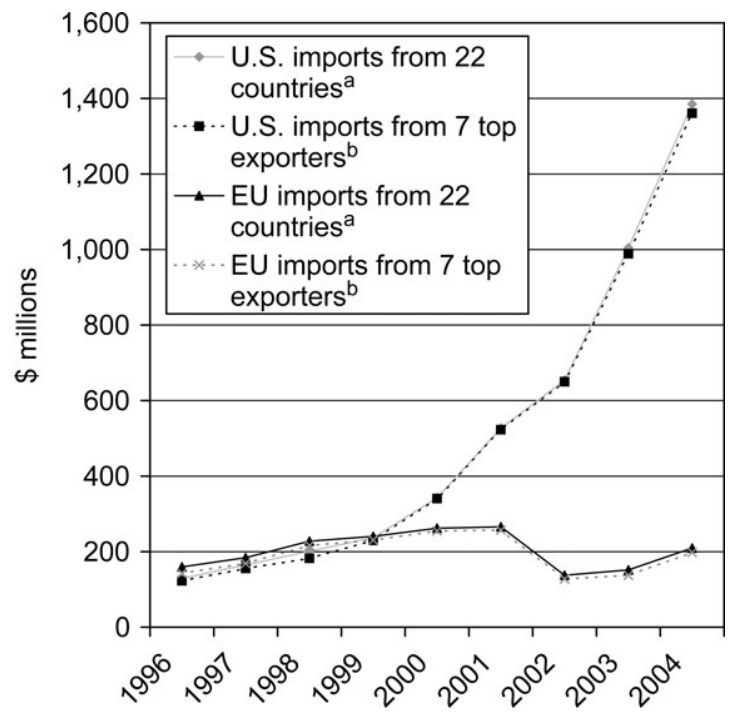

Note: a Benin, Botswana, Cameroon, Cape Verde, Ethiopia, Ghana, Kenya, Lesotho, Madagascar, Malawi, Mali, Mozambique, Namibia, Niger, Nigeria, Rwanda, Senegal, Sierra Leone, Swaziland, Tanzania, Uganda, and Zambia. 'BBotswana, Cameroon, Ghana, Kenya, Lesotho, Madagascar, Namibia, Nigeria, and Swaziland. Source: Portugal-Perez (2007) based on the WTO Integrated Data Base ${ }^{\text {a }}$ 
as much access as Everything But Arms (with slightly more lenient rules on cumulation). In effect, nothing changed for them on this front, and along with other ACP countries they largely continued to request access under Cotonou, with which they were familiar, rather than Everything But Arms. But AGOA's special regime did not merely trigger a catch up of U.S.-bound exports toward already high levels of EU-bound exports; it dwarfed them. Thus, unlike AGOA's special regime neither Cotonou nor Everything But Arms appeared to have offered a preference mix (tariff preferences and rules of origin) conducive to export growth.

Because the data in figure 2 are computed at the HS- 6 product level, it is safe to assume that heterogeneity in export composition is largely controlled for. This is confirmed by formal econometric evidence. In a model that controls for differences in preference margins and for demand shifters in the EU and U.S. markets, Portugal-Perez (2007) finds that relaxing rules of origin for apparel (captured by a dummy variable corresponding to the introduction of the AGOA's special regime) raised apparel exports significantly for beneficiary countries. Because the special regime was not introduced in the same year for all countries, its effects are well identified statistically, and Portugal-Perez' results strongly suggest that the difference in performance apparent in figure 2 is indeed attributable to differences in rules of origin regimes.

AGOA's special regime seems to have encouraged growth not only at the "intensive margin" (higher volumes) but also at the "extensive margin" (diversification by addition of new products). As new products were exported to both countries (an active extensive margin), the rate of increase in new products was several orders of magnitude higher for the U.S.-bound goods than for EU-bound ones, which is an important achievement. Product diversification is one measure of industrialization, particularly at early stages of the economic development process (Cadot, Carrère, and Strauss-Kahn 2007 and references therein). Controlling for other factors, countries that have a more diversified industrial base enjoy less volatile growth and are better poised to absorb shocks. Only three countries in Sub-Saharan Africa-Lesotho, Madagascar, and Senegal-export more than 50 products to either the European Union or the United States. Thus, if the development objective of rules of origin is to be taken seriously, encouraging export growth at the extensive margin is important, and in this regard Everything But Arms and Cotonou's performance are again disappointing compared with that of AGOA's special regime.

Taken together, the brief discussion here on the Asian exception and the comparison of AGOA with the Everything But Arms initiative suggests two results:

Limited differences between preferential regimes can have drastic effects on their performance; AGOA's relaxation of the triple transformation rule gave a significant boost to Sub-Saharan African apparel exports. 
Utilization rates are an incomplete measure of the performance of preferential regimes, as the inhibiting effect of stiff rules of origin can be felt on trade volumes as well.

\section{Indirect Evidence}

Taking inspiration from the early work by Herin (1986) for EFTA, Cadot, de Melo, and Portugal-Perez (forthcoming) applied revealed-preference arguments to estimate upper and lower bounds of compliance costs. Arguably, this nonparametric approach could be more robust than the parametric evidence reported above. By revealed preference, for products with 100 percent utilization rates the net benefit of preferences is positive for all firms. Since everyone uses the preferences, the ad valorem equivalent of compliance costs cannot be larger than the tariff-preference margin. Conversely, for products with zero percent utilization rates, since no one uses the preferences, the compliance cost cannot be smaller than the preference margin.

For remaining sectors (those with utilization rates between 0 and 100 percent) the story is more complicated because of firm heterogeneity, so assumptions must be made. Cadot, de Melo, and Portugal-Perez (forthcoming) argue that, firm heterogeneity notwithstanding, the average exporter (in terms of compliance costs) is not too far from indifference between the preferential and the most favored nation regimes, which means that the compliance cost is about equal to the tariffpreference margin. Applying this reasoning gives trade-weighted ad valorem estimates of 4.7-8.2 percent depending on sectors for PANEURO and 1.8-1.9 percent for NAFTA — values in line with the econometric estimates of Carrère and de Melo (2006) reported earlier.

How then should requests for preferential status be interpreted when tariff preferences are nil? Beyond (likely) errors in data transcription, the logical possibility would be that administrative costs are negligible, but this contradicts the evidence (the nonparametric approach described in the previous paragraph gave estimates of pure administrative costs slightly above 3 percent in ad valorem form). Francois, Hoekman, and Manchin (2006) elegantly addressed this problem by modeling the determinants of utilization rates for EU trade with ACP countries in a switching-regression framework where the relationship between the variable of interest (utilization rates) and explanatory variables varies between two regimes: one for low-margin sectors and the other for high-margin ones. The dividing point between the two regimes is determined by the data using an algorithm developed by Hansen (2000). ${ }^{10}$ They found that exporters start requesting preferences when preferential margins are in the 4.0-4.5 percent range, a result that 
is also broadly consistent with the nonparametric estimates of compliance costs reported above.

Other studies using aggregate bilateral trade data also suggest costs associated with the presence of rules of origin. Using a gravity model of bilateral trade, Anson et al. (2005) find that after controlling for the other determinants of the volume of bilateral trade, including the presence of free trade agreements, the intensity of bilateral trade is inversely related to the values taken by the $R$-index. Using a similar framework, Augier, Gasiorek, and Tang (2005) find that the volume of bilateral trade is lower when cumulation is on a bilateral rather than a full basis, leading them to suggest that rules of origin should be relaxed to allow for full cumulation.

The evidence reported so far in this article is overwhelming: rules of origin are burdensome and foster economic inefficiency. But this article also argues that they have a role in combating trade deflection, so calling them trade barriers is not enough. To make progress in designing "clean" rules of origin, a key part of the argument is to tell apart, in their current characteristics (and in particular their restrictiveness), how much is attributable to their antideflection role compared with how much is simply capture by special interests. Portugal-Perez (2006) tries to address this issue by decomposing variations in the $R$-index into a component attributable to trade deflection and one associated with lobbying or political-economy motives. He estimates this decomposition for Mexican textile and apparel exports to the United States under NAFTA using the following equation

$$
R o O_{i}=\beta\left[T D_{i}\right]+\gamma\left[P E_{i}\right]+\varepsilon_{i}
$$

where $\left(R o O_{i}\right)$ is $R$-index values at the HS-6 level. The regressors are the trade deflection vector, which includes a proxy for the extent of product differentiation (the more homogeneous the product, the more there is to gain from arbitraging even small differences in external tariffs), and differences in external tariffs (the larger these differences the more there is to arbitrage). Political-economy variables including the level of the United States' most favored nation tariff (a proxy for lobbying power) revealed comparative-advantage indexes and the value of Mexican exports to the rest of the world (a proxy for potential penetration of the U.S. market).

Portugal-Perez finds strong and quite robust correlations, suggesting that both sets of factors are at work in explaining cross-sectoral variations in rules of origin restrictiveness. Using estimated parameter values, he constructs a counterfactual distribution of $R$-index values across goods in the absence of political-economy correlates (that is, by setting $\gamma=0$ in equation (5). The two distributions (actual and counterfactual) are reported in figure 3. They show that political-economy concerns (which shift the actual distribution to the right of the counterfactual) contribute to the overall restrictiveness of rules of origin. Drawing on the 
Figure 3. Counterfactual Distribution for $R$-Index

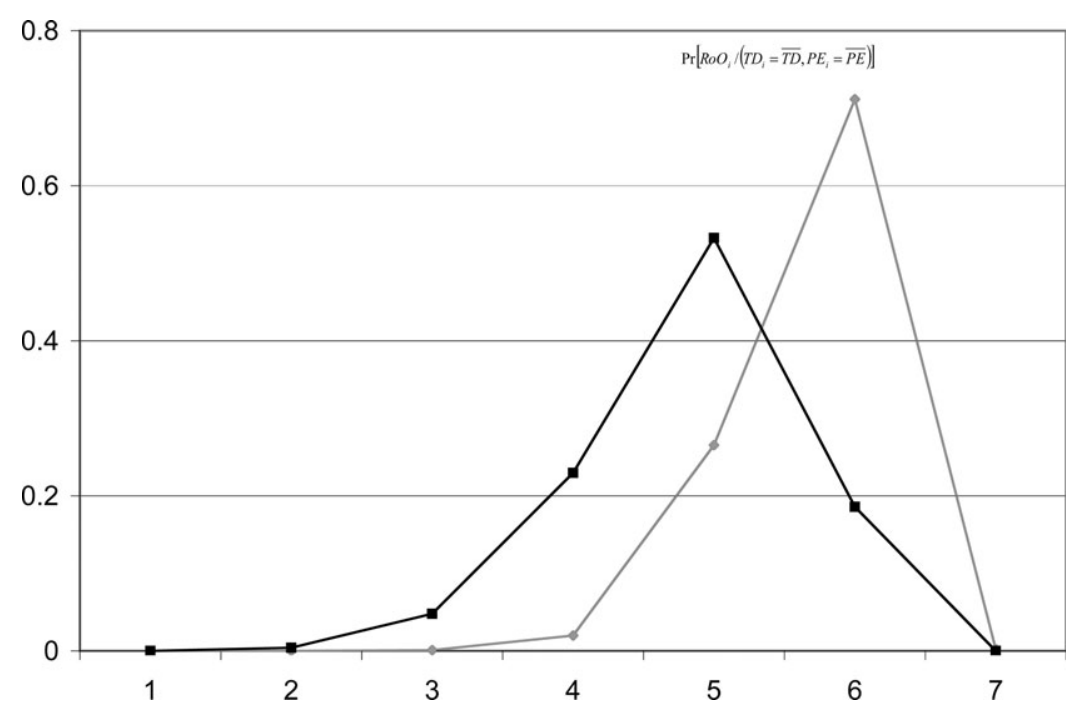

Source: Portugal-Perez 2006, figure 3.

estimates discussed earlier by Carrère and de Melo (2006), he concludes that capture by special interests may have raised the costs of rules of origin an average of 3.5-11 percent of good value, a very steep increase in the face of the shallow preferences that are generally granted.

Simulation methods provide another way of obtaining orders of magnitude of rules of origin effects on trade. Francois, Hoekman, and Manchin (2006) use their estimate of compliance costs to simulate the effects of trade liberalization by developed economies on low-income countries in a multiregional trade model. Despite preference erosion, low-income countries gain instead of losing from trade liberalization by the European Union because the "rectangle" deadweight losses associated with compliance costs are eliminated.

Table 6 provides alternative estimates from a partial-equilibrium perspective, taking as an example a GSP country benefiting from a 10 percent preferential margin in the EU (or U.S.) market (row 1) but forced to raise its minimum local content from the value in row 3 (40 percent, except in column 5 ) to the value in row 4 (50 percent, except in column 5). When present, administrative costs, also expressed as a percentage of the unit price, are given in row 2 . The table's bottom three rows show the effect of rules of origin on equilibrium exports and prices.

Column 1 shows the benefits that accrue to the GSP producer from receiving a 10 percent preference margin with no constraint on the sourcing of inputs. For this constellation of elasticity (all are on the high side to reflect the likelihood 
that products from different origin are close substitutes, whether at the intermediate- or final-good level), the pass-through is 2.9 percent (row 7) out of a preference margin of 10 percent, in line with econometric estimates mentioned in the section on direct evidence. Exports increase by 16 percent, but costs do not increase because inputs are bought at constant world prices.

Column 2 shows what happens when the producer must reduce the use of nonoriginating materials to meet a value content rule of 50 percent (a 25 percent increase from column 1). For the example, where value added is 20 percent and unconstrained purchases of nonoriginating intermediate goods equal 75 percent of the value of total intermediate good purchases, raising the minimum local content from 40 to 50 percent implies that purchases of nonoriginating intermediate goods must be reduced to 62.5 percent. The result of forcing producers to shift away from preferred intermediate goods is a higher unit production cost resulting in lower export volume, with the 1.9 percent increase in unit cost passed on to EU and U.S. consumers. Matters get worse if substitution possibilities for materials from different origins are low (column 3), which might be the representative of industries with a lot of transformation and many production stages. ${ }^{11}$

Column 4 mirrors column 2 but adds administrative compliance costs of 2.5 percent. This further penalizes the GSP producer, even though part of this cost increase can again be passed on to consumers in the importing country. Of course, if GSP producers were competing with close substitutes, they would be unable to pass on the price increase. Finally, column 5 considers a simulation that might be fairly representative of an industry with enough originating intermediate good purchases that the shift to a 40 percent minimum local content would not affect producers much. In this case, the net price to producers might go up by about one-third of the preference margin, resulting in a modest supply response of about 10 percent.

\section{Implications for Reform}

If rules of origin are a legitimate way to prevent trade deflection by mandating that sufficient processing take place in the preferential zone, the accumulated evidence reported in this article indicates that they have gone vastly beyond that role, becoming akin to technical barriers to trade. Various estimates suggest that the compliance costs associated with meeting origin requirements in preferential trade agreements range between 3 and 5 percent of final product prices-a very stiff price tag for preference margins that are often thin, given that most favored nation tariffs are low in most sectors except textiles and apparel. Controlling for preferential margins, utilization rates are lower in product lines with more 
restrictive rules of origin and when producers are limited in the sourcing of their intermediate good purchases.

Because of their trade-inhibiting effects, rules of origin hinder the integration of preference-receiving least developed economies in the world economy and thus work at cross-purposes with the development-policy goals of EU and U.S. preferences. For Sub-Saharan African countries supplying apparel products to the European Union, even high utilization rates hide obstacles to export growth caused by the double-transformation requirement imposed on those products.

This article also shows that in the case of the European Union and the United States, the two largest users of preferential trade agreements, rules of origin are stricter for products with tariff peaks where preferences could be most valuable. The correlation between the presence of tariff peaks and that of highly restrictive rules of origin suggests capture by protectionist interests, a hypothesis largely confirmed by political-economy theory and evidence. Moreover, because rules of origin have so far escaped WTO disciplines-whereas other, more traditional trade-policy instruments are brought under increasingly stringent ones-they stand as a choice candidate for creeping protectionism.

Despite the prevalence of capture by special interests, two quasi-natural experiments point to broad directions for reform. First, the relaxation of the U.S. triple-transformation requirement in textile and apparel for Sub-Saharan African producers under AGOA has proved to strongly encourage export diversification and growth compared with exports destined to the European Union, which are subject to stricter rules under the Everything But Arms initiative (which otherwise features similar preference margins). Second, low-income Asian countries operating under simple and benign rules of origin have been able to rapidly integrate themselves into cross-border supply chains and have, as a result, tremendously benefited from the verticalization of world trade.

These observations suggest that a multilateral agenda for preferential rules of origin reform, a key step in bringing preferential trade agreements under WTO disciplines, would have to move along three dimensions: harmonization, simplification, and relaxation. Harmonization between trading blocs, although unlikely to be attained anytime soon, is desirable in view of the "spaghetti bowl" of preferential trade agreements and is a prerequisite for simple and mutually consistent cumulation rules. The European Union has set an example in this regard with the PANEURO system, designed precisely to facilitate cumulation across preferential zones.

For simplification arguments in favor of a single across-the-board rule are much like those in favor of uniform tariffs - that is, simplification fosters transparency and mitigates capture. Clearly, technical requirements should be targeted for elimination first because they are the most opaque, difficult to harmonize, and capture-prone instruments. Leaving aside agricultural products that could still 
operate under the wholly obtained criterion and keeping in mind that any uniform rule will affect industries and countries differently, two avenues could be considered; a simple change of tariff classification, say at the subheading (HS-6) level so that it is not too restrictive or a uniform value-content rule.

Some information can be gleaned in this regard from the European Union's recent review. The change of tariff classification has the advantage of simplicity, transparency, and low administrative costs. But the Harmonized System tariff nomenclature was designed to collect trade statistics, not to separate products and confer origin, so defining the change of tariff classification at a uniform level would produce erratic results across sectors. This would call for exceptions to uniformity, opening up a Pandora's Box of special deals. Moreover, a change of tariff classification that would not easily lend itself to differential treatment for least developed economies should be an objective (see below).

Notwithstanding conceptual clarity, a value content rule may be less than straightforward to apply in practice. ${ }^{12}$ It may increase producer risk due to the sensitivity of costs to exchange-rate, wage, and commodity-price fluctuations and is also burdensome to apply for customs officials. However, it is simple to specify and transparent, and it allows for differential treatment of least developed economies. All told, if properly specified, it is the best candidate for an across-theboard criterion, ideally in combination, at the exporter's choice, with a change of tariff classification. In this spirit Tumurchudur (2007b) estimated for each good the maximum foreign content that would make a value content rule equivalent to the current array of NAFTA's rules of origin. Her method consisted of three steps.

First, she estimated the statistical relationship between utilization rates and rules of origin, including value content rules. Second, she inverted that relationship to find the rate of a value content rule that would give a utilization rate equal to the current one. Third, she calculated the trade-weighted average of that maximum content. This neutral average turns out to be a very low 21 percent of the good's value in maximum foreign content, confirming the diagnosis that NAFTA's rules of origin are very restrictive. More important, this rate provides a transparent and fully comparable benchmark which is to base discussions of reform and harmonization.

If the slow pace of harmonization talks at the WTO is any indication, the reform agenda described above may be overambitious by several orders of magnitude; even if the European Commission manages to complete the agenda, competition between systems may trigger similar rounds of simplification elsewhere, including in free trade agreements between developing economies in Africa and Latin America, whose rules of origin are often directly inspired by NAFTA and PANEURO. However, the outcome of the EU reform process is highly uncertain at this stage; moreover, even if the plan to adopt an across-the-board value content 
criterion survives, it is not clear that the rate of this value content rule would be uniform. Nor is it certain (perhaps even less) that it would relax the restrictiveness of the current system.

More immediate, win-win steps may be a better way to proceed. A simple first step would consist of eliminating rules of origin requirements for tariff lines with preferential margins below 3 or perhaps even 5 percent (the rate could be agreed upon in the context of multilateral negotiations at the WTO). This would be an all-around winning proposition since resources would be freed for other purposes, especially in developing economies, but also for consumers in developed economies, who would no longer bear part of the increased costs associated with compliance. A second step would be to allow for differential treatment not across sectors, but across beneficiaries, with low value content requirements for least developed economies reflecting the empirical observation that the "slices" of value added in least developed economies through cross-border production networks are generally thin. In this regard, the experience with the U.S. special regime granted in textile and apparel to African producers under AGOA is most encouraging.

\section{Appendix. Glossary of terms}

Harmonized System. A system of classification for traded goods in which all countries belonging to the World Customs Organization participate. It classifies traded goods into (by increasing order of disaggregation) 21 sections (one digit), 99 chapters (two digits), 1,417 items (four digits), and 4,998 subitems (six digits). Beyond that (eight- and ten-digit), classification systems are no longer harmonized across countries and are subject to frequent classification changes.

Preference Margin. The difference between most favored nation and preferential tariffs.

Preference Pass-Through. The percentage of a tariff-preference margin that is "appropriated" by exporters in the form of an increase in the export price. It is inversely related to the bargaining power of importers.

Preferential Status. Whether a good is eligible for the preferential tariff rate.

Technical Requirement. Rule of origin that imposes a certain type of production process or the use of certain specified technology or standard. 
Trade Deflection. Use of the country with the lowest external tariff by importers in a free trade agreement (which reduces tariff revenue for others). This notion is distinct from Vinerian "trade diversion."

Utilization Rate. Share of exports shipped under the preferential (as opposed to most favored nation) regime.

\section{Regime-wide Rules of Origin}

Absorption or Roll-up. Principle that allows nonoriginating materials that have acquired origin by meeting specific processing requirements to maintain this origin when used as input in a subsequent transformation. In other words, the nonoriginating materials are no longer taken into account in calculating value added. The roll-up or absorption principle is used in most preferential trade agreements (in particular, the EU GSP and the Cotonou Agreement), although a few have exceptions for the automotive sector.

Cumulation. Principle that allows producers from one member country in a preferential trade agreement to import nonoriginating materials from another member country without affecting the final product's originating status. There are three types of cumulation rules: bilateral, diagonal, and full Bilateral cumulation. It is the most common type and applies to trade between two partners in a preferential trade agreement. It stipulates that producers in country A can use inputs from country B without affecting the final good's originating status as long as the inputs satisfy the area's rules of origin.

Diagonal Cumulation. Under diagonal cumulation (the basic principle of the EU's PANEURO system), countries in a preferential trade agreement can use materials that originate in any member country as if the materials originated in the country where the processing is undertaken. Under full cumulation all stages of processing or transformation of a product within countries in a preferential trade agreement can be counted as qualifying content regardless of whether the processing is sufficient to confer originating status to the materials themselves. Full cumulation allows for greater fragmentation of the production process than bilateral and diagonal cumulation.

Duty Drawbacks. Refunds to exporters of tariffs paid on imported intermediate good inputs. Many preferential trade agreements, especially in the Americas, mandate the elimination of duty-drawback schemes for exports to partner countries on the grounds that a duty drawback claimed by a producer in country A to export to country B would put that producer at a competitive advantage compared with 
domestic producers in country B given that the producer in country A already benefits from the elimination of intrabloc tariffs. Eliminating duty drawbacks as part of a preferential trade agreement can harm the profitability of final-good assembly for export to partner countries in the area, although tariff escalation, when present, already provides some protection for final-assembly operations (because it implies lower tariffs on intermediate goods than on final ones).

\section{Product-Specific Rules of Origin}

Allowance. An amendment to a mandated change of tariff classification that excludes some categories from noneligibility (that is, a final good belonging to, say, chapter 11 can embody imported inputs belonging to any other chapter or from chapter 11 itself but between headings $X$ and $Y$ ).

Change of Tariff Classification. Rule of origin requiring that a final good made with imported inputs belong to a Harmonized System category that differs from that of its imported inputs (as proof of transformation). The mandated change of tariff classification can be specified at the chapter (two digits), heading (four digits), subheading (six digits), or item (eight digits) level.

Exception. An amendment to a mandated change of tariff classification that excludes some categories from eligibility (that is, a final good belonging to, say, chapter 11 can embody imported inputs belonging to any other chapter except headings $\mathrm{X}$ to $\mathrm{Y}$ ).

Value Content. Rule of origin requiring a minimum percentage of local value (materials or value added) or a maximum percentage of foreign value.

\section{Notes}

Olivier Cadot is Professor of Economics at the University of Lausanne, associated scholar at Centre d'Etudes et de Recherches sur le Développement International (CERDI), and fellow at the Centre for Economic Policy Research (CEPR); his email address is olivier.cadot@unil.ch. Jaime de Melo (corresponding author) is Professor of Economics at the University of Geneva, associated scholar at CERDI, and fellow at CEPR; his email address is demelo@ecopo.unige.ch. The authors thank Paul Brenton and Marcelo Olarreaga for many useful suggestions and their colleagues and co-authors Céline Carrère, Antoni Estevadeordal, Alberto Portugal-Perez, Akiko Suwa-Eisenmann, and Bolormaa Tumurchudur for permission to draw on joint work. They also thank three referees for comments on a previous draft.

1. According to this same tally, 45 developing economies having signed bilateral trade agreements with a developed country, and 90 of the 109 preferential trade agreements between developed and developing economies have been created since 1990.

2. According to a survey administered by the World Customs Organization to customs officials in developing economies (as reported by Brenton and Imawaga 2004), 67 percent of respondents in 
Sub-Saharan Africa agree that dealing with rules of origin under overlapping trade agreements causes problems, and a majority also agrees that rules of origin are more labor-intensive. Administering rules of origin detracts from other objectives of tax collection and trade facilitation.

3. Because meeting the requirements is difficult and appears unnecessarily complex, in view of the European Commission's objective to grant some preferential access to its market for GSP-eligible countries, on 16 March 2004 the commission adopted Communication COM (2005) on "The Rules of Origin in Preferential Trade Arrangements." The communication explores alternative rules of origin that would be simpler and more development friendly. A key proposal under consideration is to replace the current product-specific rules of origin with a single rule based on a minimum of originating value added.

4. By comparison, the average preferential margin (computed over tariff lines with positive tariffs) was 4.5 percent for NAFTA (almost all tariffs had been eliminated on NAFTA trade by 2001), 2.4 percent for GSP-eligible countries, and 4.6 for ACP countries (not eligible for Everything But Arms status). Data for the European Union are for 2004, when 62 percent of trade for GSP-eligible countries and over 80 percent of trade for ACP countries took place at zero tariffs (some ACP also benefited from Everything But Arms status at zero tariffs in the EU market).

5. Krishna (2006) discusses other effects that are more difficult to quantify: effects such as rules of origin-jumping investment and effects on intermediate prices. Thoenig and Verdier (2006) also consider the implications of rules of origin for multinationals confronted with outward-processing decisions.

6. The United States rarely uses a value content criterion as the sole requirement for origin, and when it does it tends to rely on a single 40 percent foreign content requirement. The European Union has value content criteria ranging from 50 to 15 percent of domestic value added.

7. Cumulation is, in principle, only diagonal (see the glossary in the appendix), but the domestic content can be calculated as an aggregate of value added in any ASEAN member state; so in effect AFTA provides for full cumulation, although, as noted by Brenton (2006), the rules stipulate that the final stage of manufacture must be carried out in the exporting member state (what constitutes "the final stage" is not defined). Because vertical links and outsourcing are very important in Asia, full cumulation considerably relaxes the requirements of satisfying origin.

8. To drive home the importance of trade in intermediate goods, consider the following example. On the basis of the input-output data in Baldwin (2006, table 1 for Indonesia, Malaysia, Philippines, and Thailand (middle-income Asian countries), an average of 35-40 percent of intermediate goods are sourced outside AFTA. For example, take an activity with 10 percent value-added and 40 percent nonoriginating intermediate goods - that is, 36 percent of the final unit product price is nonoriginating. Originating value for this activity would be 64 percent. Then take the plausible example of an activity with the same value added but with 60 percent of materials nonoriginating; originating value falls to 46 percent, barely above the 40 percent minimum currently stipulated in AFTA.

9. The special regime was recently extended until 2015. Figure 2 lists the 22 beneficiary countries.

10. The algorithm is in essence a grid search over cutoffs whose criterion is the minimization of the concentrated sum of squared errors of the ordinary least squares regressions in the two regimes.

11. The decline in exports to the preferential-giving destination suggests that producers would choose to export under most favored nation status. In the illustrative simulations reported here, with constant elasticity throughout and smooth substitution possibilities across the origin for intermediate good purchases and export destination sales, producers pass on cost increases to consumers.

12. The authors of this article are aware of concerns voiced by the private sector in the course of the EU review about the practical difficulty of a value content criterion for small firms and, if based on costs, its potential to force unwanted disclosure of strategic information to powerful EU buyers that would enhance their ability to squeeze rents from developing country producers. 


\section{References}

Anson, J., O. Cadot, C. Carrère, A. Estevadeordal, J. de Melo, and B. Tumurchudur. 2005. "Rules of Origin in North-South Preferential Trading Arrangements with an Application to NAFTA." Review of International Economics 13(3):501-17.

Augier, P., M. Gasiorek, and C. Tang. 2005. "The Impact of Rules of Origin on Trade Flows." Economic Policy 20(43):567-24.

Baldwin, R. 2006. "Managing the Noodle Bowl: The Fragility of East Asian Regionalism." CEPR Discussion Paper 5561. Centre for Economic Policy Research, London.

Brenton, P. 2006. "Notes on Rules of Origin with Implications for Regional Integration in South East Asia." World Bank, Washington, D.C.

Brenton, P., and H. Imagawa. 2004. "Rules of Origin, Trade and Customs." In L. de Sokol, and J. Wulf eds., Customs Modernization Handbook. Washington, D.C.: World Bank.

Brenton, P., and M. Manchin. 2003. "Making EU Trade Agreements Work: the Role of Rules of Origin." The World Economy 26(5):755-69.

Brenton, P., and C. Özden. 2005. "Trade Preferences for Apparel and the Role of Rules of Origin: The Case of Africa." World Bank, Washington, D.C.

Cadot, O., C. Carrère, and V. Strauss-Kahn. 2007. "Export Diversification: What's Behind the Hump?" University of Lausanne, Switzerland.

Cadot, O., J. de Melo, and A. Portugal-Perez. 2005. "Market Access and Welfare under Free Trade Agreements: the Case of Textiles under NAFTA.” World Bank Economic Review 19(3):379-405.

. (forthcoming). "Rules of Origin for Preferential Trading Arrangements: Implications for the ASEAN FTA of EU and US Experience." Journal of Economic Integration.

Cadot, O., J. de Melo, and E. Pondard. 2006. "Evaluating the Consequences of a Shift to a Value-added Method for Determining Origin in the European Union's GSP Preferential Scheme." Report prepared for the European Commission, Brussels.

Cadot, O., A. Estevadeordal, and A. Suwa-Eisenmann. 2006. "Rules of Origin as Export Subsidies." In O. Cadot eds., The Origin of Goods: Rules of Origin in Regional Trade Agreements. London: Oxford University Press.

Cadot, O., C. Carrère, J. de Melo, and B. Tumurchudur. 2006. "Product Specific Rules of Origin in EU and US Preferential Trading Arrangements: an Assessment." World Trade Review 5(2): 199-224.

Cadot, O., A. Estevadeordal, A. Suwa-Eisenmann, and T. Verdier eds. 2006. The Origin of Goods: Rules of Origin in Regional Trade Agreements. London: Oxford University Press.

Carrère, C., and J. de Melo. 2006. "Are Different Rules of Origin Equally Costly? Estimates from NAFTA." In O. Cadot eds., The Origin of Goods: Rules of Origin in Regional Trade Agreements. London: Oxford University Press.

Estevadeordal, A. 2000. "Negotiating Preferential Market Access: the Case of NAFTA." Journal of World Trade 34(1):141-66.

Estevadeordal, A., and K. Suominen. 2006. "Mapping Rules of Origin Around the World.” In O. Cadot eds., The Origin of Goods: Rules of Origin in Regional Trade Agreements. London: Oxford University Press.

Francois, J., B. Hoekman, and M. Manchin. 2006. "Preference Erosion and Multilateral Trade Liberalization." World Bank Economic Review 20(2):197-216.

Hansen, B. 2000. "Sample Splitting and Threshold Estimation." Econometrica 68(3):575-603. 
Herin, J. 1986. "Rules of Origin and Differences between Tariff Levels in EFTA and in the EC.” EFTA Occasional Paper 13. Geneva: European Free Trade Agreement.

Krishna, K. 2006. "Understanding Rules of Origin.” In O. Cadot eds., The Origin of Goods: Rules of Origin in Regional Trade Agreements. London: Oxford University Press.

Krueger, A.O. 1998. "Free Trade Areas versus Customs Unions." Journal of Development Economics 54(1):169-87.

Olarreaga, M., and C. Özden. 2005. "AGOA and Apparel: Who Captures the Tariff Rent in the Presence of Preferential Market Access?" World Economy 28(1):63-77.

Özden, C., and G. Sharma. 2006. "The Price Effects of Preferential Market Access: Caribbean Basin Initiative and the Apparel Sector." World Bank Economic Review 20(2):241-60.

Portugal-Perez, A. 2006. "Disentangling the Determinants of Rules of Origin in North-South Preferential Trade Agreements: Evidence for NAFTA." University of Geneva. 2007. "The Costs of RoO in Apparel: African Apparel Exports to the US and EU.” University of Geneva.

Stevens, C., M. Gasiorek, J. Chweijczak, and J. Kennan. 2006. “Creating Development Friendly Rules of Origin in the EU." Overseas Development Institute, International Economic Development Group, London. (www.odi.org.uk/iedg/publications/Rules_of_Origin_FinalReport.pdf).

Thoenig, M., and T. Verdier. 2006. "The Impact of RoO on Strategic Outsourcing: An IO Perspective." In O. Cadot eds., The Origin of Goods: Rules of Origin in Regional Trade Agreements. London: Oxford University Press.

Tumurchudur, B. 2007a. "Rules of Origin and Market Access in the Europe Agreements." University of Lausanne, Switzerland. . 2007b. "Reforming NAFTA's Rules of Origin." University of Lausanne, Switzerland.

World Bank. 2005. Global Economic Prospects 2005: Trade, Regionalism and Development. Washington, D.C.

WTO (World Trade Organization). 2002. "Rules of Origin in Regional Trade Agreements." WT/REG/ W/45. Geneva, Switzerland.

Wulf, L. de, and J. Sokol eds. 2004. Customs Modernization Handbook. Washington, D.C.: World Bank. 